\title{
ANALISIS PENGARUH PAD, DAU DAN DAK TERHADAP KEMISKINAN MELALUI BELANJA DAERAH DI KOTA BITUNG
}

\author{
Dewi I,S Paulus, Rosalina A.M. Koleangan, Daisy S.M. Engka \\ Ekonomi Pembangunan - Fakultas Ekonomi dan Bisnis \\ Universitas Sam ratulangi
}

\begin{abstract}
ABSTRAK
Penelitian ini dibuat untuk mengetahui sejauh mana pengaruh Pendapatan Asli Daerah (PAD), Dana Alokasi Umum (DAU) dan Dana Alokasi Khusus (DAK) terhadap kemiskinan melalui Belanja Daerah di Kota Bitung. Berdasarkan data time series tahun 2005-2015 dan diolah berdasarkan metode analisa regresi berganda untuk pengujian analisis jalur yang digunakan dapat diketahui bahwa hubungan antara PAD, DAU, DAK terhadap kemiskinan melalui Belanja Daerah adalah hubungan negatif. Dimana penurunan 1 persen kemiskinan adalah kontribusi dari PAD 0.6216 persen, DAU 4,7930 persen dan DAK 0.2101 persen melalui Belanja Daerah Kota Bitung. Sedangkan secara keseluruhan diketahui bahwa jika terjadi kenaikan 1 persen pada Belanja Daerah maka akan terjadi penurunan angka kemiskinan sekitar 0.1856 persen.
\end{abstract}

Kata kunci: Kemiskinan, Belanja Daerah, Pendapatan Asli Daerah, Dana Alokasi Umum, Dana Alokasi Khusus

\begin{abstract}
This research was made to determine the extent of the influence of Local Revenue, General Allocation Fund, and Specific Allocation Fund on poverty through Local Expenditure in Bitung. Based on years of 2005-2015 time series data and processed based on the method of multiple regression analysis to test used path analysis showed that the relationship between Local Revenue, General Allocation Fund, and Specific Allocation Fund against poverty through local expenditure is a negative relationship. Where a 1 percent reduction of poverty is the contribution of Local Revenue 0.6216 percent, 4.7930 percent General Allocation Fund and Specific Allocation Fund 0.2101 percent through Local Expenditure of Bitung City Government. While overall note that if there is a 1 percent increase in local expenditure there will be a decline in the poverty rate of about 0.1856 percent.
\end{abstract}

Key Word: Poverty, Local Expenditure, Regional Income, General Allocation Fund, Specific Allocation Fund 
Latar Belakang Masalah.

\section{PENDAHULUAN}

Kemiskinan merupakan musuh dari tujuan utama otonomi daerah. Dimana, pemberian otonomi yang luas kepada pemerintah daerah dimaksudkan untuk mempercepat terwujudnya kesejahteraan masyarakat melalui peningkatan pelayanan, pemberdayaan dan peran serta masyarakat. Hal ini telah membawa konsekuensi pada pemerintah daerah dalam mengatur serta mengurus kepentingan daerahnya sendiri menurut prakarsa sendiri, berdasarkan aspirasi masyarakat dan tentunya sesuai dengan peraturan perundang-undangan yang berlaku. Dalam menjalankan otonomi daerah, Pemerintah Daerah dituntut untuk menjalankan roda pemerintahan yang efektif, efisien, dan mampu mendukung peran masyarakat dalam meningkatkan pemerataan dan keadilan dengan mengembangkan seluruh potensi yang dimiliki oleh masing-masing daerah sehingga pada akhirnya kemiskinan bisa terentaskan dan mendatangkan kesejahteraan masyarakat. Prinsip-prinsip otonomi daerah harus dipenuhi oleh pemerintah daerah, yaitu demokratisasi, transparansi, akuntabilitas publik dan partisipasi masyarakat. Artinya, pemerintah daerah diberikan kewenangan secara luas, nyata, bertanggung jawab dan proporsional dalam mengatur, membagi dan memanfaatkan sumber daya nasional serta perimbangan keuangan pusat dan daerah. Pemberlakuan Undang-Undang nomor 23 tahun 2014 tentang pemerintah daerah dengan esensi kebijakan otonomi daerah yang bergulir dewasa ini merupakan wujud dari kewenangan dalam bidang keuangan daerah. Kebijakan otonomi daerah itu dimaksudkan untuk semakin mendekatkan pemerintah kepada masyarakat agar pelayanan yang diberikan menjadi semakin baik. Menurut Suparmoko (2002), dengan semakin mendekatkannya pemerintah kepada masyarakat diharapkan pelayanan publik dapat diwujudkan lebih baik sesuai dengan kebutuhan masyarakat. Pembangunan di sektor ekonomi merupakan hal yang paling esensi dalam mengembangkan potensi dan membangun daerah. Hal ini, membutuhkan peran aktif seluruh komponen masyarakat dalam menunjang program pembangunan di bidang ekonomi. Membangun perekonomian berarti menciptakan lapangan pekerjaan baru, meningkatkan produktivitas dan meningkatkan pendapatan per kapita penduduk sehingga terjadi perbaikan tingkat kesejahteraan. Menurut (Mudrajad 2004) Pembangunan ekonomi daerah adalah suatu proses dimana pemerintah daerah dan seluruh komponen masyarakat mengelola berbagai sumber daya yang ada dan membentuk suatu pola kemitraan untuk menciptakan suatu lapangan pekerjaan baru dan merangsang perkembangan kegiatan ekonomi dalam daerah tersebut. Menurut UU No. 23 tahun 2014 tentang pemerintahan daerah untuk pelaksanaan kewenangan pemerintah daerah, pemerintah pusat akan mentransfer dana perimbangan pada pemerintah daerah. Dana perimbangan tersebut terdiri dari Dana Alokasi Umum (DAU), Dana Alokasi Khusus (DAK) dan Bagi Hasil Pajak Pusat (BHPP). Sedangkan pemerintah daerah memiliki sumber pendanaan sendiri berupa Pendapatan Asli Daerah (PAD), Pinjaman Daerah, dan Lain-Lain Penerimaan Daerah Yang Sah, yang kesemuanya tersebut di atas adalah termasuk dalam komponen Pendapatan Daerah. Menurut Suparmoko (2011) Sumber-sumber keuangan daerah terdiri dari:
1. PAD
2. Dana perimbangan (Dana Bagi Hasil, DAU, DAK)
3. Pinjaman Daerah
4. Dana Dekonsentrasi
5. Dana Tugas Pembantuan 
Tiga sumber dana yang pertama langsung dikelola oleh pemerintah daerah melalui Anggaran Pendapatan Belanja Daerah, sedangkan sumber dana lainnya dikelola oleh pemerintah pusat melalui kerja sama dengan pemerintah daerah. Jadi sumber pendanaan bagi pelaksanaan pemerintahan daerah terdiri atas PAD, dana perimbangan (dana transfer), dan lain-lain pendapatan yang sah. Kebijakan penggunaan dana diserahkan kepada pemerintah daerah (Prakosa, 2004). Dalam pelaksanaan desentralisasi, peran dana transfer tidak dapat dihindarkan mengingat otonomi yang dilimpahkan menuntut daerah untuk dapat menyelesaikan berbagai urusan pemerintahan yang menjadi wewenang daerah dalam hal pembiayaan. Untuk menyelenggarakan otonomi daerah luas nyata dan bertanggungjawab, pemerintah daerah dituntut mampu menggali sumber-sumber keuangan sendiri dalam rangka membiayai penyelenggara pemerintahan, pembangunan dan kemasyarakatan yang menjadi kewenangan. Hal ini menandakan bahwa daerah harus berusaha untuk mampu meningkatkan Pendapatan Asli Daerah (PAD), baik meningkatkan penerimaan sumber-sumber PAD yang ada maupun penggalian sumber PAD yang baru sesuai dengan ketentuan yang ada serta memperhatikan kondisi dan potensi ekonomi masyarakat, karena PAD merupakan tolak ukur bagi daerah dalam menyelenggarakan dan mewujudkan otonomi daerah. Pada prinsipnya semakin besar sumbangan PAD terhadap Anggaran Pendapatan dan Belanja Daerah (APBD) akan menunjukkan semakin kecil ketergantungan daerah kepada pusat. Pada umumnya Anggaran Pendapatan dan Belanja Daerah (APBD) suatu daerah didominasi oleh sumbangan pemerintah dan sumbangan-sumbangan lain, yang diatur dengan peraturan perundang-undangan. Hal ini menyebabkan daerah sangat tergantung kepada pemerintah pusat, (Suparmoko, 2011). Hakikat Anggaran Pendapatan Belanja Daerah (APBD) yang disusun oleh pemerintah daerah adalah harus dapat meningkatkan kesejahteraan masyarakat di wilayahnya, sehingga setiap belanja dalam program dan kegiatan yang direncanakan dalam APBD harus bertumpu pada hal tersebut. Belanja Daerah merupakan bagian utama dalam APBD yang berkaitan dengan peran pemerintah dalam meningkatkan kesejahteraan masyarakat. Pemerintah Kota Bitung dalam menjalankan pembangunannya memerlukan pendanaan, yang dalam pengelolaan keuangan daerah disebut Pendapatan. Pendapatan tersebut baik bersumber dari Kota Bitung dalam bentuk Pendapatan Asli Daerah (PAD) maupun pendapatan yang bersumber dari luar daerah berupa dana perimbangan ataupun lain-lain pendapatan yang sah digunakan untuk membiayai segala kebutuhan daerah yang di anggarkan dalam Anggaran Pendapatan Belanja Daerah (APBD), yang dikelompokan dalam belanja daerah.Dalam membiayai semua kebutuhan pembangunan daerah maka pemerintah kota Bitung sudah tentu harus melihat kemampuan keuangan daerah dalam hal ini pendapatan daerah. Dalam membiayai pelaksanaan pembangunan daerah di kota Bitung maka pendapatan daerah memegang peran penting, sebab dengan pendapatan yang cukup maka pembangunan yang direncanakan akan berjalan dengan baik. Sehubungan dengan adanya kebijakan otonomi daerah, hal penting yang harus diperhatikan adalah ketersediaan dana (pendapatan daerah) untuk membiayai tugas dankewajiban yang makin bertambah. Tingginya Pendapatan Asli Daerah (PAD) merupakan penentu keberhasilan otonomi daerah, selain faktor kualitas aparat pemerintah daerah dan tingkat pendidikan masyarakat yang tinggi. Kemiskinan merupakan salah satu dari beberapa permasalahan pokok yang menghambat pembangunan ekonomi suatu daerah. Setidaknya terdapat tiga masalah pokok yang harus diperhatikan dalam mengukur pembangunan suatu negara atau daerah, yaitu 1) Apa yang terjadi pada tingkat kemiskinan, 2) Apa yang terjadi terhadap pengangguran, dan 3) Apa yang terjadi 
terhadap ketimpangan dalam berbagai bidang (Mudrajad 2004). Masalah pokok tersebut saling berkaitan dan saling mempengaruhi satu dengan lainnya. Tingkat kemiskinan dipengaruhi oleh jumlah pengangguran dan selanjutnya pasti berdampak terhadap ketimpangan dalam berbagai bidang. Jika salah satu dari tiga hal tersebut mengalami penurunan ataupun peningkatan, maka dua hal lainnya juga mengalami dampaknya. Kemiskinan pada umumnya disebabkan oleh laju pertumbuhan penduduk yang tidak dibarengi dengan jumlah lowongan kerja yang tersedia, angkatan kerja yang tidak produktif, tingkat pendidikan yang rendah dan distribusi pendapatan yang timpang sehingga menyebabkan ketidaksamaan pola kepemilikian sumber daya. Hal-hal tersebut menyebabkan bertambahnya pengangguran, meningkatnya tingkat kriminalitas, bertambahnya angka Anak Putus Sekolah, kesempatan pendidikan menurun, tingkat kesehatan dibawah Standar Pelayanan Minimum sehingga berdampak pada buruknya kondisi perkembangan generasi penerus. Pemerintah dalam hal ini memiliki tugas dan tanggung jawab untuk bertindak dalam meningkatkan keseluruhan taraf hidup masyarakat dalam usahanya untuk keluar dari kemiskinan. Pendapatan dan Belanja memiliki peranan penting dalam meningkatkan pendapatan masyarakat, mengatasi masalah pertumbuhan ekonomi, kemiskinan serta pengangguran. Keberpihakan Pemerintah sebagai pengelola keuangan (Pendapatan dan Belanja) adalah strategi yang paling ampuh untuk permasalahan-permasalahan tersebut. Pengelolaan keuangan daerah berkaitan erat dengan penyelenggaraan urusan pemerintahan melalui pelaksanaan desentralisasi, fungsi pemerintahaan tertentu dilimpahkan kepada pemerintah daerah dengan tujuan untuk meningkatkan nilai tambah dalam penyelenggaraan pemerintahan. Keberhasilan suatu daerah dalam mewujudkan kesejahteraan masyarakat sangat tergantung pada kebijakan pemerintah daerah dalam meningkatkan Pendapatan Asli Daerah dan pengalokasian belanja sesuai prioritas pembangunan. Alokasi belanja yang baik tentunya diharapkan dapat meningkatkan kesejahteraan masyarakatnya yang dapat dilihat dari indikator pertumbuhan ekonomi dan penurunan angka kemiskinan. Angka kemiskinan biasanya juga dipengaruhi oleh pengeluaran pemerintah. Alokasi belanja yang kurang tepat dan kurang optimal bisa menyebabkan bertambahnya angka kemiskinan. Data angka kemiskinan Kota Bitung menurut Badan Pusat Statistik Kota Bitung menunjukan bahwa telah terjadi penurunan jumlah penduduk miskin di tahun 2014 yaitu 12.600 jiwa dari tahun 2013 sejumlah 12.900 jiwa. Jika dipresentasekan maka jumlah penduduk miskin di tahun 2014 merupakan capaian tingkat kemiskinan terbaik di Kota Bitung dalam 10 tahun terakhir yaitu sebesar 6,34\%. Meskipun demikian data menunjukan telah terjadi peningkatan jumlah penduduk miskin pada tahun 2015 di Kota Bitung, berjumlah 14.160 jiwa atau bertambahnya penduduk miskin sebanyak 1.560 jiwa. Secara keseluruhan capaian usaha pemerintah Kota Bitung dalam menurunkan angka kemiskinan mengalami fluktuasi namun tetap terjadi trend penurunan meskipun tidak terlalu signifikan.

\section{Perumusan Masalah}

Berdasarkan latar belakang permasalahan yang telah diuraikan di atas, maka yang menjadi permasalahan dalam penelitian ini adalah:

1. Bagaimana Pengaruh PAD terhadap angka kemiskinan melalui Belanja Daerah

2. Bagaimana Pengaruh DAU terhadap angka kemiskinan melalui Belanja Daerah

3. Bagaimana Pengaruh DAK terhadap angka kemiskinan melalui Belanja Daerah

4. Bagaimana Pengaruh PAD, DAU dan DAK terhadap angka kemiskinan melalui Belanja Daerah 


\section{Tujuan Penelitian}

Adapun yang menjadi tujuan dalam penelitian ini adalah:

1. Untuk menganalisis pengaruh PAD terhadap angka kemiskinan melalui Belanja Daerah

2. Untuk menganalisis pengaruh DAUterhadap terhadap angka kemiskinan melalui Belanja Daerah belanja daerah kota Bitung.

3. Untuk menganalisis pengaruh DAKterhadap angka kemiskinan melalui Belanja Daerah

4. Untuk menganalisis pengaruh PAD, DAU dan DAK terhadap angka kemiskinan melalui Belanja Daerah

\section{Data Dan Sumber Data}

\section{METODE PENELITIAN}

Data yang digunakan dalam penelitian ini merupakan data sekunder dengan jenis data time series. Data tersebut berupa data historical angka kemiskinan Kota Bitung Tahun 2005-2015, Laporan Realisasi Anggaran Pendapatan Dan Belanja Daerah Pemerintah Kota Bitung Tahun 2005-2015 yang berupa realisasi Pendapatan yang terdiri dari Pendapatan Asli Daerah (PAD), Dana Transfer, Lain-lain pendapatan yang sah dan realisasi Belanja Daerah (BD) yang bersumber dari:

1. Badan Pusat Statistik (BPS) Kota Bitung

2. Badan Pengelola Keuangan dan Barang Milik Daerah Kota Bitung

3. Badan Perencanaan dan Pembangunan Daerah (BAPPEDA) Kota Bitung

\section{Metode Pengolahan Data}

Penelitian ini dilakukan dengan menggunakan analisis deskriptif dan kuantitatif.Analisis deskriptif didasarkan pada studi literarur melalui artikel, buku-buku dan hasil penelitian yang berhubungan dengan Kemiskinan, Anggaran Pendapatan dan Belanja Daerah (APBD) Kota Bitung. Sedangkan dalam analisis kuantitatifnya digunakan model ekonometrika untuk mencerminkan hasil dan pembahasan yang dinyatakan dalam angka.

\section{Ruang Lingkup Penelitian}

Dalam menganalisis pengaruh Pendapatan Asli Daerah, Dana Alokasi Umum (DAU)dan Dana Alokasi Khusus (DAK) terhadap Kemiskinan melalui Belanja Daerah, maka ditetapkan ruang lingkup penelitian dengan menggunakan variable bebas antara lain adalah PAD, DAU, DAK dengan variable antara adalah Belanja Daerah dan variable terikatnyaadalah Kemiskinan.

\section{Definisi dan Pengukuran Variabel}

Definisi operasional variabel adalah suatu definisi yang diberikan pada suatu variabel atau dengan cara memberikan arti atau menspesifikasikan kegiatan ataupun membenarkan suatu operasional yang diperlukan untuk mengukur variable tersebut. Variabel yang digunakan dalam penelitian ini meliputi variable bebas, variable antara dan variable terikat. PAD, DAU, DAK merupakan variable bebas, Belanja Daerah merupakan variable antara, sedangkan kemiskinan merupakan variable terikat. Adapun definisi operasional sebagai berikut:

- Kemiskinan 
Kemiskinan adalah ketidakmampuan seseorang untuk memenuhi kebutuhan makanan maupun non makanan yang bersifat mendasar. Kemiskinan diukur dari jumlah penduduk miskin. Jumlah Penduduk Miskin adalah jumlah penduduk di suatu wilayah tertentu yang dikategorikan penduduk miskin berdasarkan kemampuan memenuhi kebutuhan dasar (basic needs approach). Penduduk miskin menurut definisi dan data Badan Pusat Statistik, dimana definisinya adalah penduduk yang memiliki rata-rata pengeluaran perkapita perbulan di bawah garis kemiskinan. Dimana, Garis Kemiskinan merupakan penjumlahan dari Garis Kemiskinan Makanan (GKM) dan Garis Kemiskinan Non Makanan (GKNM). Data jumlah penduduk miskin yang digunakan adalah data dari BPS tahun 2005-2015.

\section{- Belanja Daerah}

Belanja daerah adalah semua pengeluaran pemerintah daerah pada suatu periode anggaran. Belanja Daerah dalam penelitian ini dapat diketahui dari pos belanja daerah dalam laporan realisasi anggaran pemerintah Kota Bitung tahun anggaran 2005-2015.

- Pendapatan Asli Daerah

PAD yang terdiri dari hasil pajak daerah, retribusi daerah, pendapatan dari laba perusahaan daerah dan lain-lain pendapatan yang Sah. Pendapatan asli daerah dalam laporan realisasi anggaran pemerintah Kota Bitung tahun anggaran 2005-2015

- Dana Alokasi Umum

DAU adalah transfer yang bersifat umum dari pemerintah pusat ke pemerintah daerah untuk mengantisipasi ketimpangan horizontal dengan tujuan utama pemerataan kemampuan keuangan antar daerah. DAU diperoleh dengan melihat dari dana perimbangan yang ada di laporan realisasi anggaran pemerintah Kota Bitung tahun anggaran 2005-2015.

- Dana Alokasi Khusus

DAK adalah dana yang bersumber dari pendapatan APBN yang dialokasikan kepada daerah tertentu dengan tujuan untuk membantu mendanai kegiatan khusus yang merupakan urusan daerah dan sesuai dengan prioritas nasional. DAK diperoleh dengan melihat dari dana perimbangan yang ada di laporan realisasi anggaran pemerintah Kota Bitung tahun anggaran 2005-2015.

\section{Metode Analisis}

Metode analisis yang digunakan adalah analisis kualitatif dan kuantitatif, yang akan dijelaskan sebagai berikut :

1. Kualitatif dilakukan dengan menggunakan beberapa instrumen analisis seperti tabel dan grafik serta analisis rasio yang dapat mencerminkan uraian analisis penelitian secara teratur dan saling mendukung.

2. Kuantitatif dilakukan dengan menggunakan model ekonometrika dengan bantuan program Eviews 7 dan Microsoft Excel.

\section{Model Ekonometrika}

Analisis data pada penelitian ini menggunakan analisis regresi berganda untuk pemenuhan ketentuan analisis jalur pada variable-variabel penelitian. Berdasarkan hipotesa penelitian, maka desain penelitian dapat digambarkan dan dibuatkan persamaan regresinya sebagai berikut:

Gambar 1 Desain Penelitian 


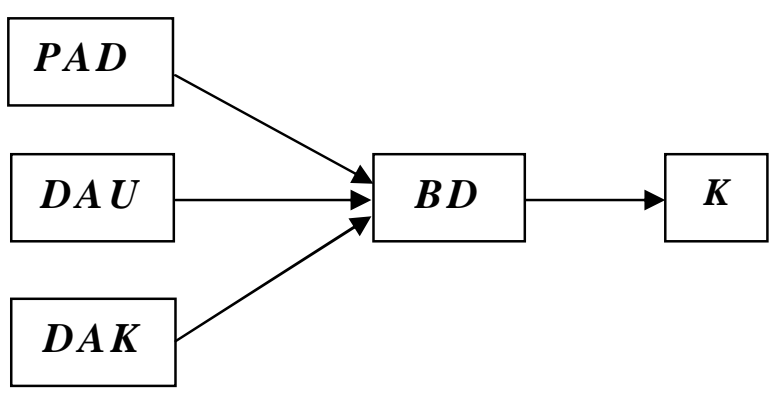

Adapun persamaan regresi dari desain penelitian tersebut adalah sebagai berikut:

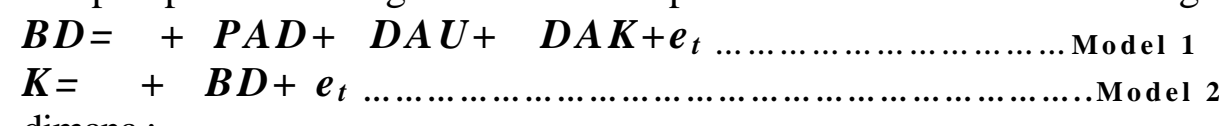

dimana :

$\begin{array}{lll}\boldsymbol{\alpha} & : & \text { Konstanta } \\ \boldsymbol{\beta}, \boldsymbol{Y} & : & \text { Koefisien Regresi } \\ \boldsymbol{P A} \boldsymbol{D}: & \text { Pendapatan Asli Daerah } \\ \boldsymbol{D A} \boldsymbol{A}: & \text { Dana Alokasi Umum } \\ \boldsymbol{D A} \boldsymbol{K}: & \text { Dana Alokasi Khusus } \\ \boldsymbol{B D} & : & \text { Belanja Daerah } \\ \mathrm{t} & : & \text { Periode waktu penelitian (2005-2015) } \\ e & : & \text { Error term } \\ \boldsymbol{K} & : & \text { Kemiskinan }\end{array}$

Adapun model regresi dari desain diatas terdiri dari 2 model. Dimana, model pertama melihat keterikatan variable-variabel bebas (PAD, DAU, DAK) terhadap variabel antara(BD). Selanjutnya variabel BD hasil regresi pada model pertama dijadikan variabel bebas untuk melihat hasil regresinya terhadap Kemiskinan. Menurut Nachrowi (2006), untuk menjadikan nilai variable-variabel yang akan dianalisis menjadi seimbang sekaligus menunjukan kofisien slope pada hasil output regresi yang merupakan tingkat perubahan variable tidak bebas (persen) bila terjadi perubahan pada variable bebas (persen), maka kedua model tersebut akan ditransformasikan kedalan bentuk log-natural sehingga model tersebut menjadi:
$L B D=\alpha+\beta L P A D+\beta L D A U+\beta L D A K+e_{t}$
Model 1
$L K=\alpha+\gamma L B D+e_{t}$
Model 2

dimana :

\begin{tabular}{llll}
$\boldsymbol{\alpha}$ & $:$ & & Konstanta \\
$\boldsymbol{\beta}, \mathbf{Y}$ & $:$ & \multicolumn{2}{l}{ Koefisien Regresi } \\
$\boldsymbol{L P} \boldsymbol{A} \boldsymbol{D}$ & $:$ & Pertumbuhan Pendapatan Asli Daerah \\
$\boldsymbol{L D A} \boldsymbol{D}$ & $:$ & Pertumbuhan Dana Alokasi Umum \\
$\boldsymbol{L D A} \boldsymbol{K}$ & $:$ & Pertumbuhan Dana Alokasi Khusus \\
$\boldsymbol{L B D}:$ & & Pertumbuhan Belanja Daerah \\
$\mathrm{t}$ & $:$ & Periode waktu penelitian (2005-2015) \\
$\boldsymbol{e} \quad:$ & Error term \\
$\boldsymbol{L K} \quad:$ & Pertumbuhan Kemiskinan
\end{tabular}

\section{Uji Model}

Pengujian yang dilakukan adalah uji klasik berganda sekaligus uji analisis jalur yang dibuat.Ghozali dan Fuad (2008) menyatakan bahwa asumsi yang paling fundamental dalam analisis multivariate adalah normalitas. Analisis jalur pastinya 
termasuk dalam analisis multivariate karena pasti menggunakan lebih dari 1 variabel, bahkan minimal 3 variabel(1 variabel bebas, 1 intervening/antara dan 1 terikat). Syaratsyarat yang harus dipenuhi adalah data tersebut harus terdistribusikan secara normal, tidak mengandung multikoloniaritas, dan heterokedastisitas. Namun, apabila hanya terdapat satu varibel bebas, maka uji multikolinearitas tersebut tidak perlu digunakan. Menurut Allison (2012) multikolinearitas terjadi apabila "there are strong linear dependencies among the explanatory variables". Selain itu, prasyarat yang lain adalah uji linearitas, skala datanya harus interval, dan uji autokorelasi. Menurut Olobatuyi (2006) the assumptions for path analysis include: linearity, interval level of measurement, normality, and autocorrelation.Namun, autokorelasi bisa diabaikan apabila data anda berupa data cross section bukan time series. Uji autokorelasi bisa diabaikan dalam penelitian yang menggunakan data cross-section (Stokes, 1997; Armstrong, 2001; Doane, Seward, Seward, 2008; Verbeek, 2008; dan Abrams, 2010).Berdasarkan pendapat para ahli dari bahan literatur yang ada, maka uji analisis jalur yang dilakukan antaralain uji normalitas, multikolinearitas, linieritas dan autokorelasi. Uji tersebut juga merupakan uji klasik sehingga hanya akan ditambahkan uji heteroskedastisitas sebagai pelengkap pada uji model yang telah dibuat.

\section{Uji Normalitas}

Pengujian normalitas memiliki tujuan untuk menguji apakah dalam model regresi, variabel penganggu atau residual memiliki distribusi normal. Seperti diketahui bahwa uji t mengasumsikan bahwa nilai residual mengikuti distribusi normal. Kalau asumsi ini dilanggar maka uji statistik menjadi tidak valid untuk jumlah sampel kecil. Untuk menguji normalitas data, penelitian ini menggunakan Jarque-Berra Test.

\section{Uji Multikolinearitas}

Multikolineariti dapat diartikan sebagai hubungan linear diantara beberapa atau semua variabel independen dalam sebuah model regresi. Uji ini diperlukan agar CLRM ( Classical Linear Regression Model ) terpenuhi, yaitu suatu kondisi dimana terdapat hubungan yang linear sempurna di antara beberapa atau semua variabel independen dalam sebuah model regresi. Multikolineariti dapat dideteksi apabila nilai $\mathrm{R}^{2}$ yang tinggi dan uji-F yang signifikan, tetapi banyak koefisien regresi dalam uji-t yang tidak signifikan, Nachrowi (2006). Pendeteksian adanya multikolineariti dapat juga dengan cara menghitung koefisien korelasi antar variabel independen, Winarno (2007).

\section{Uji Heteroskedastisitas}

Salah satu asumsi yang harus dipenuhi agar taksiran parameter dalam model regresi bersifat BLUE maka semua residual error mempunyai varian yang sama. Kondisi seperti itu disebut dengan homokedastis. Sedangkan bila varian tidak konstan atau berubah-ubah disebut heterokedastis. Untuk mendeteksi adanya masalah heterokedastisitas akan digunakan uji-formal, yaitu Glejser, Breusch-Pagan-Godfrey, danHarveyyang telah tersedia dalam program siap pakai Eviews 7.

\section{Uji Linieritas}

Linieritas merupakan asumsi awal yang seharusnya ada dalam model regresi linier. Uji linieritas dapat dengan mudah dilakukan pada regresi linier sederhana, yaitu membuat scatter diagram dari variabel bebas dan terikatnya. Apabila scatter diagram menunjukkan bentuk garis lurus maka dapat dikatakan bahwa asumsi linieritas 
terpenuhi.Uji linearitas bertujuan untuk mengetahui apakah dua variabel mempunyai hubungan yang linear atau tidak secara signifikan. Uji ini biasanya digunakan sebagai prasyarat dalam analisis korelasi atau regresi linear. Dua variabel dikatakan mempunyai hubungan yang linear bila signifikansi (Linearity) kurang dari 0,05.

\section{Uji Autokorelasi}

Uji autokorelasi digunakan untuk mengetahui ada atau tidaknya penyimpangan asumsi klasik autokorelasi yaitu korelasi yang terjadi antara residual pada satu pengamatan dengan pengamatan lain pada model regresi. Prasyarat yang harus terpenuhi adalah tidak adanya autokorelasi dalam model regresi. Metode pengujian yang sering digunakan adalah dengan uji Durbin-Watson (uji DW) dengan ketentuan sebagai berikut:

1) Jika d lebih kecil dari dL atau lebih besar dari (4-dL) maka hopotesis nol ditolak, yang berarti terdapat autokorelasi.

2) Jika d terletak antara dU dan (4-dU), maka hipotesis nol diterima, yang berarti tidak ada autokorelasi.

3) Jika d terletak antara dL dan dU atau diantara (4-dU) dan (4-dL), maka tidak menghasilkan kesimpulan yang pasti.

\section{Perumusan hipotesis}

Dalam persamaan ekonometrik berupa suatu regresi Ordinary Least Square (OLS), perumusan hipotesis perlu dilakukan untuk menguji model analisis jalur sudah memenuhi perhitungan statistic dan melihat kebenaran korelasi variabel-variabel independen yang mempengaruhi variabel dependen secara bersamaan. Adapun perumusannya sebagai berikut.

Model I:

Ho: $\beta 1=\beta 2=\beta 3=0$ [tidak ada pengaruh yang berarti antara variabel independen $(P A D, D A U, D A K)$ terhadap variabel dependen (Belanja Daerah)]

$\mathrm{Ha}: \beta 1, \beta 2, \beta 3 \neq 0 \quad$ [ada pengaruh variabel independen (PAD, DAU, DAK)terhadap variabel dependen (Belanja Daerah)].

Model II:

Ho: $\beta 1=\beta 2=\beta 3=0$ [tidak ada pengaruh yang berarti antara variabel independen (Belanja Daerah) terhadap variabel dependen (Kemiskinan)]

$\mathrm{Ha}: \beta 1, \beta 2, \beta 3 \neq 0 \quad$ [ada pengaruh variabel independen (Belanja Daerah) terhadap variabel dependen (Kemiskinan)].

\section{Kriteria Pengujian}

Kriteria pengujian menggunakan uji hipotesis nol (null hypothesis)

Ho tidak ditolak jika $\mathrm{F}_{\text {hitung }}<\mathrm{F}_{\text {tabel }}$

Model I: Ho tidak ditolak berarti variabel PAD, DAU dan DAKtidak mempunyai pengaruh yang berarti terhadap Belanja Daerah.

Model II: Ho tidak ditolak berarti variabel Belanja Daerah tidak mempunyai pengaruh yang berarti terhadap Kemiskinan.

Ho ditolak apabila $\mathrm{F}_{\text {hitung }}>\mathrm{F}_{\text {tabel }}$

Model I: Ho ditolak berarti variabel PAD, DAU dan DAKsecara keseluruhan mempunyai pengaruh yang berarti terhadap Belanja Daerah. 
Model II: Ho ditolak berarti variabel Belanja Daerah secara keseluruhan mempunyai pengaruh yang berarti terhadap Kemiskinan.

\section{Uji t-statistik}

Untuk mengetahui apakah variabel independen mempunyai pengaruh terhadap variabel dependen secara parsial, maka dilakukan uji t.

$$
t=\frac{\hat{\beta_{i}}-\beta_{i}}{S E\left(\hat{\beta_{i}}\right)}
$$

Keterangan :

$\hat{\beta}_{i}=$ hasil estimasi

$\beta_{i}=$ parameter sesuai dengan hipotesis Ho

$\operatorname{se}\left(\beta_{\mathrm{i}}\right)=$ standar error regresi

\section{Perumusan Hipotesis}

Model I:

Ho : $\beta_{1}=0 \quad$ (tidak ada pengaruh secara berarti dari perubahan variabel bebasPAD, DAU dan DAKterhadap variabel tidak bebas (Belanja Daerah)].

Hi $: \beta_{1} \neq 0 \quad$ [ada pengaruh secara berarti dari perubahan variabel bebasPAD, DAU dan DAK terhadap variabel tidak bebas (Belanja Daerah)]

Model II:

Ho: $\beta_{1}=0 \quad$ (tidak ada pengaruh secara berarti dari perubahan variabel bebas(Belanja Daerah)terhadap variabel tidak bebas (Kemiskinan)].

$\mathrm{Hi}: \beta_{1} \neq 0 \quad$ [ada pengaruh secara berarti dari perubahan variabel bebas(Belanja Daerah) terhadap variabel tidak bebas (Kemiskinan)]

\section{Kriteria Pengujian}

Bila $-\mathrm{t}_{\text {tabel }}<\mathrm{t}_{\text {hitung }}<\mathrm{t}_{\text {tabel }}$ maka Ho tidak ditolak dan menolak Hi

Berarti:

Persamaan I:variabel independen (PAD/DAU/DAK)secara individual tidak berpengaruh terhadap variabel dependen (Belanja Daerah)

Persamaan II:variabel independen (Belanja Daerah)tidak berpengaruh terhadap variabel dependen (Kemiskinan)

Jika $t_{\text {hitung }}>t_{\text {tabel }}$ dan $t_{\text {hitung }}<-t_{\text {tabel }}$ maka Ho ditolak dan Hi tidak ditolak

Berarti:

Persamaan I: variabel independen (PAD/DAU/DAK)secara individual berpengaruh terhadap variabel dependen (Belanja Daerah)

Persamaan II: variabel independen (Belanja Daerah)berpengaruh terhadap variabel dependen (Kemiskinan)

\section{Koefisien Determinasi}

Dalam pengukuran ketepatan suatu garis regresi digunakan koefisien determinasi (R-Squared). Koefisien determinasi (R-Squared) yaitu angka yang menunjukkan besarnya derajat kemampuan menerangkan variabel bebas terhadap variabel tak bebas dari fungsi tersebut. Nilai R-Squaredberkisar $0<\mathrm{R}^{2}<1$ dimana semakin mendekati 1 maka semakin dekat pula hubungan antara variabel bebas dengan variabel tak bebas, atau dapat dikatakan model tersebut baik, demikian pula sebaliknya. 


\section{HASIL PENELITIAN DAN PEMBAHASAN \\ Hasil Penelitian dan Pembahasan}

Analisis data pada penelitian ini menggunakan hasil statistik deskriptif dan analisis jalur dengan menggunakan regresi linear berganda. Model yang digunakan adalah regresi linear berganda. Terdiri dari 2 model, dimana model pertama adalah Belanja Daerah sebagai variabel tidak bebas dan PAD, DAU dan DAK sebagai variabel bebasnya. Model regresi berikutnya adalah melakukan regresi linear pada variabel kemiskinan sebagai variabel tidak bebas dengan variabel bebasnya adalah Belanja Daerah hasil regresi linear berganda pada model pertama.

Model pertama yang dihitung dengan menggunakan e-views versi 7 menggunakan pendekatan Ordinary Least Squares (OLS) adalah Belanja Daerah (BD) sebagai variabel tidak bebas dan PAD, DAU dan DAK sebagai variabel bebas.

Hasil regresi yang dilakukan terhadap model pertama diperoleh hasil nilai R-Squared sebagai koefisien determinasi adalah 0.965678. Angka ini menunjukkan bahwa variabel-variabel bebas pada persamaan tersebut, yaitu PAD, DAU dan DAK secara bersama-sama menerangkan $\pm 96 \%$ variasi dalam Belanja Daerah dipengaruhi oleh ketiga variabel bebas tersebut, sedangkan sisanya sebesar $\pm 4 \%$ dijelaskan oleh faktor-faktor lain di luar model (Hasil regresi terlampir)

\section{Pengujian Model 1}

\section{Uji Normalitas}

Uji normalitas yang dimaksud dalam asumsi klasik pendekatan OLS adalah (data) residual yang dibentuk model regresi linier terdistribusi normal, bukan variabel bebas ataupun variabel terikatnya. Dalam pengujian ini digunakan JarqueBera Test untuk pengujian terhadap residual terdistribusi normal atau tidak. Terdistribusi normal tidaknya residual secara sederhana dengan membandingkan nilai Probabilitas JB (Jarque-Bera) hitung dengan tingkat alpha 0,05 (5\%). Apabila Prob. JB hitung lebih besar dari 0,05 maka dapat disimpulkan bahwa residual terdistribusi normal dan sebaliknya, apabila nilainya lebih kecil maka tidak cukup bukti untuk menyatakan bahwa residual terdistribusi normal. Nilai Prob. JB hitung sebesar 0,514645>0,05 sehingga dapat disimpulkan bahwa residual terdistribusi normal yang artinya asumsi klasik tentang kenormalan pada Model 1 telah dipenuhi (Data diolah terlampir).

\section{Uji Multikolinearitas}

Untuk Uji Multikolinearitas pada penelitian ini, menggunakan VIF

\section{(Variance Inflation \\ Factors).}

Hasil pada kolom Centered VIF untuk setiap variabel di bawah 10, maka dapat dikatakan tidak terjadi multikolinieritas. Dengan demikian model 1 yang dipakai terbebas dari adanya multikoliniearitas (Data diolah terlampir).

\section{Uji Heteroskedastisitas}

Heteroskedasitisitas terjadi pada saat residual dan nilai prediksi memiliki korelasi datau pola hubungan. Pola hubungan ini tidak hanya sebatas hubungan yang linier, tetapi dalam pola yang berbeda juga dimungkinkan. Oleh karena itu untuk menghindari 
Heteroskedasitisitas maka peneliti menggunakan beberapa metode uji yaitu: Glejser ,Breusch-Pagan-Godfrey, dan Harvey.

\section{Uji Linieritas}

Uji Linieritas yang dilakukan pada penelitian ini berpatokan pada nilai Prob. F. Tingkat alpha pada nilai Prob. F harus lebih besar dari tingkat alpha 0.05 (5\%), jika lebih kecil maka Ho ditolak.

Nilai Prob. F hitung pada baris F-statistic kolom Probability. Pada kasus ini nilainya 0,0850 lebih besar dari 0,05 sehingga dapat disimpulkan bahwa model regresi telah memenuhi asumsi linieritas (Data diolah terlampir).

\section{Pengujian Model 2}

\section{Uji Normalitas}

Sebagaimana yang dilakukan untuk pengujian tingkat kepercayaan penelitian pada model satu, demikian dilakukan normalitas pada model kedua ini. Dalam pengujian ini juga digunakan Jarque-Bera Test untuk pengujian terhadap residual terdistribusi normal atau tidak. Nilai Prob. JB hitung sebesar 0,729576 >

0,05 sehingga dapat disimpulkan bahwa residual terdistribusi normal yang artinya

asumsi klasik tentang kenormalan pada Model 2 telah dipenuhi (Data diolah terlampir).

\section{Uji Multikolinearitas}

Untuk Uji Multikolinearitas pada Model 2 juga menggunakan Test VIF (Variance Inflation Factors). Centered VIF untuk variabel X4 adalah 1 atau dibawah 10, maka dapat dikatakan tidak terjadi multikolinieritas. Dengan demikian model 2 yang dipakai terbebas dari adanya multikoliniearitas (Data diolah terlampir).

\section{Uji Heteroskedastisitas}

Sama seperti uji model pertama, peneliti juga menggunakan beberapa metode test yaitu: Glejser ,Breusch-Pagan-Godfrey, dan Harvey untuk uji Heteroskedasitisitas.

Nilai Prob. F hitung sebesar 0.1118 lebih besar dari tingkat alpha $0.05(5 \%)$ sehingga berdasarkan uji hipotesis, Ho diterima yang artinya tidak terjadi heteroskedastisitas.

Nilai Prob. F hitung sebesar 0.6544 lebih besar dari tingkat alpha 0,05 (5\%) sehingga, berdasarkan uji hipotesis, Ho untuk model 2 diterima yang artinya tidak terjadi heteroskedastisitas.

Nilai Prob. F hitung sebesar 0.6826 lebih besar dari tingkat alpha 0,05

(5\%) sehingga, berdasarkan uji hipotesis, Ho untuk model 2 diterima yang artinya tidak terjadi heteroskedastisitas.

\section{Uji Linieritas}

Uji Linieritas yang dilakukan pada model 2 tetap berpatokan pada nilai Prob. F. Tingkat alpha pada nilai Prob. F harus lebih besar dari tingkat alpha 0.05 (5\%), jika lebih kecil maka Ho untuk Model 2 ditolak.

Nilai Prob. F hitung pada baris F-statistic kolom Probability nilainya 0,1662 lebih besar dari 0,05 sehingga dapat disimpulkan bahwa model regresi telah memenuhi asumsi linieritas. 


\section{Uji Autokeralasi}

Uji terakhir yang digunakan untuk uji model 2 adalah uji autokorelasi, dimana digunakan untuk mengetahui ada atau tidaknya penyimpangan asumsi klasik autokorelasi.

Hasil pengolahan data yang didapat dari nilai Durbin-Watson Stat adalah 1,583789. Nilai DW hitung sebesar 1,583789 lebih besar dari 1,539 dan lebih kecil dari 2,481 yang artinya berada pada daerah tidak ada autokorelasi.

\section{Interpretasi}

Hasil regresi pada model pertama, Belanja Daerah sebagai variabel terikat PAD, DAU dan DAK sebagai variabel bebas adalah:

\section{LBD $=-0.4251+0.1154 *$ LPAD $+0.8897 *$ LDAU + 0.0390*LDAK}

Hasil regresi di atas, dapat diintepretasi sebagai berikut:

\section{Koefisien $\beta$ o (Intercept / Konstanta)}

Koefisien $\beta 0$ memberikan gambaran tentang pengaruh efek rata-rata semua faktor yang tidak dimasukkan ke dalam model pertama, dimana nilai intersepnya adalah 0.4251. Menurut Dougherty (2002), nilai intersep yang minus kadang- kadang memiliki makna yang jelas, tetapi kadang-kadang tidak. Akan tetapi menurut Mendenhall (2011), hasil regresi minus yang membutuhkan interpretasi positif untuk memenuhi logika dari kerangka berpikir dapat dibalik untuk mendapat interpretasi yang tepat. Berdasarkan teori tersebut maka hasil regresi di atas dibalik menjadi:

\section{LBD $=0.1154 *$ LPAD $+0.8897 *$ LDAU + 0.0390*LDAK - 0.4251}

Berdasarkan hasil di atas maka dapat dikatakan bahwa, jika terjadi kenaikan 1 persen pada Belanja Daerah (LBD) maka persentase kenaikan tersebut merupakan kontribusi dari 0.1154 persen LPAD, 0,8897 persen LDAU dan 0.0390 LDAK dimana total kenaikan ketiga variabel bebas tersebut untuk kenaikan 1 persen LBD adalah 1,0441 persen. Sesuai dengan hasil regresi yang telah dibalik di atas, maka nilai 1,0441 persen dikurangi 0,4251 (Koefisien $\beta 0$ ) hasilnya adalah 0,6190 persen. Sehingga kenaikan 1 persen LBD dikurangi total kenaikan dari LPAD, LDAU dan LDAK sebesar 0.6190 persen yaitu 0.3810 adalah kontribusi terjadinya kenaikan LBD dari faktor lainnya diluar dari ketiga variabel bebas tersebut. Dengan kata lain, setiap terjadi kenaikan 1 persen pada Belanja Daerah maka PAD, DAU dan DAK memberikan kontribusi sebesar sekitar 0.6190 persen dan sekitar 0.3810 persen adalah kontribusi dari faktor lain.

Hasil regresi pada model pertama diregresikan ke model kedua untuk menguji hipotesa penelitian, dengan hasil sebagai berikut:

\section{LK = 14.6344 - 0.1856*LBD}

Berdasarkan hasil tersebut maka di intepretasikan untuk koefisien $\beta 0$ bahwa Kemiskinan digerakan oleh variabel lainnya sebesar 14.6344 .

\section{Koefisien $\beta$ LPAD (variabel LPAD)}

Nilai koefisien sebesar 0.1154 yang signifikan menunjukkan adanya hubungan negatif antara LPAD melalui LBD terhadap LK. Dengan kata lain, dapat 
diinterpretasikan bahwa setiap penurunan LK (Angka Kemiskinan) di Kota Bitung sebesar 1 persen, maka didalamnya terdapat kontribusi penurunan tersebut dari LPAD (Pendapatan Asli Daerah) sebesar 0.1154 dibagi dengan 0.1856 yaitu sebesar 0.6216 persen.

\section{Koefisien $\beta$ LDAU (variabel LDAU)}

Koefisien dari variabel LDAU adalah 0.8897 juga menunjukkan signifikansi adanya hubungan negatif antara LDAU melalui LBD terhadap LK. Sehingga dapat diinterpretasikan bahwa setiap penurunan 1 persen dari LK (Angka Kemiskinan) di Kota Bitung, maka kontribusi LDAU (Dana Alokasi Umum) melalui LBD (Belanja Daerah) adalah sebesar 4,7930 persen yang didapat dari perhitungan kontribusi LDAU terhadap LBD yaitu 0.8897 persen dibagi

0.1856 persen.

\section{Koefisien $\beta$ LDAK (variabel DAK)}

Hubungan yang negatif antara LDAK terhadap LK melalui LBD terlihat dengan adanya nilai koefisien yang signifikan untuk LDAK sebesar 0.039. Dimana nilai tersebut dibagi dengan nilai koefisien LBD sebesar 0.8156 diperoleh 0.2101 persen kontribusi LDAK (Dana Alokasi Umum) terhadap LK (Angka Kemiskinan) melalui LBD (Belanja Daerah).

\section{Koefisien $\boldsymbol{\beta}$ LBD (variabel LBD)}

Nilai koefisien sebesar - 0. 1856 yang signifikan menunjukkan bahwa perkembangan Kemiskinan (LK) di Kota Bitung memiliki hubungan yang negatif dengan berubahnya Belanja Daerah (LBD). Hubungan ini berarti, jika terjadi 1 persen peningkatan pada Belanja Daerah maka akan terjadi penurunan angka Kemiskinan sebesar sekitar 0.1856 persen pada angka Kemiskinan Kota Bitung.

Hasil ini sesuai dengan penelitian sebelumnya oleh Hamzah (2007) dimana dikatakan bahwa Belanja dan Pendapatan memiliki hubungan positif dengan Pertumbuhan Ekonomi tetapi memiliki hubungan negatif Kemiskinan dan Pengangguran. Semakin besar pendapatan dan belanja daerah maka akan semakin meningkatkan kesejahteraan masyarakat dan menekan angka kemiskinan dan pengangguran

\section{Kesimpulan}

\section{KESIMPULAN DAN SARAN}

1) Pendapatan Asli Daerah ternyata mempunyai hubungan negatif dengan Kemiskinan melalui Belanja Daerah. Kenaikan PAD akan menyebabkan turunnya angka Kemiskinan melalui Belanja Daerah. Dimana pada setiap penurunan Kemiskinan, PAD turut memberikan kontribusi pada Belanja Daerah terhadap Kemiskinan, sehingga hal ini sesuai dengan hipotesis H1.

2) Dana Alokasi Umum ternyata mempunyai hubungan negatif dengan Kemiskinan melalui Belanja Daerah. Konstribusi DAU pada Belanja Daerah akan menyebabkan turunnya angka Kemiskinan. Hasil penelitian ini sesuai dengan hipotesis $\mathrm{H} 2$.

3) Dana Alokasi Khusus juga ternyata mempunyai hubungan negatif dengan Kemiskinan melalui Belanja Daerah. Melalui kontribusi DAK pada Belanja Daerah maka akan menurunkan Kemiskinan, dimana hal tersebut memenuhi hipotesis H3. 
4) Secara keseluruhan bahwa PAD, DAU dan DAK melalui Belanja Daerah mempunyai hubungan negatif dengan Kemiskinan. Hal ini terbukti dari kontribusi PAD, DAU dan DAK terhadap Belanja Daerah, dimana besaran tersebut merupakan konstribusi bagi Belanja Daerah sebagai variabel antara untuk penurunan angka Kemiskinan di Kota Bitung. Hasil ini membuktikan kesesuaian terhadap hipotesis $\mathrm{H} 4$.

\section{Saran}

1) Berdasarkan hasil penelitian dapat dilihat bahwa kontribusi DAU terhadap Kemiskinan di Kota Bitung melalui Belanja Daerah lebih besar dari kontribusi PAD dan DAK maka disarankan agar alokasi DAU dalam Belanja Daerah lebih proporsional mengarah pada program dan kegiatan yang mendukung penanggulangan kemiskinan, sehingga nantinya konstribusi DAU terhadap Kemiskinan di Kota Bitung melalui Belanja Daerah dapat meningkat.

2) Mengingat PAD adalah salah satu indikator kemandirian sebuah daerah dalam otonomi daerah, maka disarankan untuk dapat menggali potensi-potensi guna peningkatan PAD. Hal ini dapat meningkatkan kontribusi PAD dalam penanggulangan kemiskinan di Kota Bitung melalui Belanja Daerah, sekaligus Mengurangi ketergantungan daerah pada DAU.

\section{DAFTAR PUSTAKA}

Abdullah Syukriy, Halim Abdul. (2003) "Pengaruh Dana Alokasi Umum (DAU) dan Pendapatan Asli Daerah (PAD) Terhadap Belanja Pemerintah Daerah." Dalam Simposium Nasional Akuntansi VI, 1140-1159. 2003.

Amnah, 2014. Pengaruh Pendapatan Asli Daerah (Pad), Dana Alokasi Umum (Dau), Dana Alokasi Khusus (Dak) terhadap Pertumbuhan Ekonomi dengan Belanja Modal sebagai Variabel Intervening di Kabupaten dan Kota Provinsi Aceh, Tesis Program Pasca Sarjana USU, Medan.

Anna Yulianita dan Ratna Juwita. 2009, Pengaruh Pengeluaran Pemerintah terhadap Angka Kemiskinan di Sumatera Selatan.

Anthony Shorrocks and Rolph van der Hoeven. 2004, "Growth, Inequality, and Poverty Economic Policy, Distribution, and Poverty: The Nature of Disagreements.

Arsyad, Lincolin, 1999. Pengantar Perencanaan dan Pembangunan Ekonomi Daerah, BPFE, Yogyakarta.

Adhisasmita. 2005. Analisis Kesenjangan Pembangunan Regional : Indonesia 19922004. Jurnal Ekonomi Pembangunan Kajian Ekonomi Negara Berkembang, Vol. 9, No. 2, Hal: 129-142.

Badan Pusat Statistik Kota Bitung. Bitung Dalam Angka 2005-2014.

Barika, 2013 Pengaruh Pertumbuhan Ekonomi, Pengeluaran Pemerintah, Pengangguran dan Inflasi terhadap tingkat kemiskinan di Provinsi Se Sumatra, Jurnal Ekonomi dan Perencanaan Pembangunan Volume:05 No.01, Januari-Juni 2013.

Blakley, Edward, J. (1994). Planning Lokal Economic Development. Theory and Practice, Second Edition, USA, Sage Publikation, Inc, california.

Bjornestad, Liv, 2009, Fiscal Decentralization, Fiscal Incentives, and Pro-Poor Outcomes: Evidence from Vietnam, ADB Economic Working Series No.168, Asian Development Bank.

Boex, Jameson, dkk, 2006, Fighting Poverty Through Fiscal Decentralization. 
Camilla Mastromarco, 2014 "Poverty, inequality and growth in Albania" economic of transition.

Christine Martha Sihotang Marsoit, Rosalina Koleangan dan Richard Tumilaar, pengaruh investasi swasta dan belanja modal terhadap kemiskinan di kota manado tahun 2004-2012. ejournal.unsrat.ac.id.

Desy Suryati. 2015, Pengaruh belanja daerah berdasarkan klasifikasi ekonomi terhadap pengentasan kemiskinan dan indeks pembangunan manusia di kabupaten/kota provinsi nusa tenggara barat tahun 2007-2012. Media Bina Ilmiah, Volumen 9 No 7 Tahun 2015.

Dumairy, MA.1996. Perekonomian Indonesia. Penerbit Erlangga. Jakarta.

Erlina dan Rasdianto, 2013. Akuntansi Keuangan Daerah Berbasis Akrual, Medan.

Erlina, 2011. Metodologi Penelitian, USU Press, Medan.

Ginting, Evarina, 2013. Pengaruh Dana Alokasi Umum, Dana Alokasi Khusus, Lain Lain Pendapatan Daerah yang Sah terhadap Pertumbuhan Ekonomi dengan Desentralisasi Fiskal sebagai Variabel Moderating di Kabupaten dan Kota Provinsi Sumatera Utara, Tesis Program Pasca Sarjana USU, Medan.

Halim, Abdul, 2002. Akuntansi Keuangan Daerah, Edisi 3 Akuntansi Sektor Publik, Salemba Empat, Jakarta.

Hamzah. (2002) "Pengaruh Belanja dan Pendapatan Terhadap Pertumbuhan Ekonomi, Kemiskinan dan Pengangguran." Dalam Simposium Akuntansi \& Keuangan Sektor Publik Pertama Pasca Sarjana UPN Veteran, Surabaya, 2002.

Hamzah, Ardi. (2007). Pengaruh Belanja Dan Pendapatan Terhadap Pertumbuhan Ekonomi, Kemiskinan, Dan Pengangguran (Studi Pada APBN 1999-2006). Konferensi Penelitian. Akuntansi dan Keuangan Sektor Publik Pertama. Jatim; Pasca Sarjana PNU.

Haryanto, Tommy Prio. 2013. Pengaruh Pengeluaran Pemerintah Terhadap Pertumbuhan Ekonomi Kabupaten/Kota di Provinsi Jawa Tengah Tahun 20072011. Jurnal Ekonomi. Jurusan Ekonomi Pembangunan Fakultas Ekonomi Universitas Negeri Semarang.

https://bitungkota.bps.go.id/linkTabelStatis/view/id/2.

Junaidi Momongan, 2013 Investasi PMA dan PMDN pengaruhnya terhadap perkembangan PDRB dan penyerapan tenaga kerja serta penaggulangan kemiskinan di Sulawesi Utara.

Jhingan, M.L, (1993). Ekonomi Pembangunan dan Perencanaan, PT Raja Grafindo Persada, Jakarta.

Kementrian Keuangan Republik Indonesia (2004) Laporan Pelaksanaan Spending Performance dalam mendanai pelayanan public.

Kuncoro, Mudrajad. 2004. Otonomi dan Pembangunan Daerah, Reformasi, Perencanaan, Strategi dan Peluang. Jakarta: Airlangga.

Mangkoesoebroto, Guritno.2001.Ekonomi Publik, BPFE, Yogyakarta.

Mankiw, N.Gregory.2000.Teori Makro Ekonomi.Ed.4, Jakarta: Penerbit Erlangga.

Mehmood, R and S. Sadiq. 2010. The Relationship beetween Government Expenditure and Poverty: A Cointegration Analysis. Romanian Journal of Fiscal Policy, 1(1) : 29-37.

Merdekawati, Inggar Putri an Budiantara, Ketut. 2013. Pemodelan Regresi Spline Truncated Multivariabel Pada Faktor-Faktor yang Mempengaruhi Kemiskinan di 
Kabupaten/Kota Provinsi Jawa Tengah. Jurnal Sains Dan Seni Pomits Vol. 2, No.1, (2013) 2337-352.

Minggu, (2016) "Analisis Pengaruh Belanja Langsung, Belanja Tidak Langsung dan Investasi Swasta Terhadap Kemiskinan di Kota Bitung”, Tesis Program Pasca Sarjana Universitas Sam Ratulangi, Manado.

Norman V. Loayza, Claudio Radat (2009) "The composition of growth matter for poverty alleviation" Journal of Development Economics.

Rahayu, S. A. T. 2004. "Peranan Sektor Publik Lokal dan Pertumbuhan Ekonomi Regional di Wilayah Surakarta Tahun 1987-2000”. Jurnal Kinerja. Volume 8 (2): 133-147.

Rahma Amali, 2015 Pengaruh Pengeluaran Pemerintah Terhadap Kemiskinan Di Provinsi Sulawesi Barat (2007-2013).

Republik Indonesia, Peraturan Pemerintah Republik Indonesia Nomor 58 Tahun 2005 tentang Pengelolaan Keuangan Daerah.

Republik Indonesia, Undang-Undang No. 32 tahun 2004 tentang Pemerintah Daerah.

Rudiningtyas D.A. (2012). Pengaruh Pendapatan dan Belanja Terhadap Pertumbuhan Ekonomi, Kemiskinan, dan Pengangguran (Studi Pada APBN 2004-2008). Jurnal. Fakultas Ekonomi Universitas Islam Malang (UNISMA).

Rudi wahyudi. 2014, Analisis Pengaruh Belanja Pemerintah Dan Pertumbuhan Ekonomi Terhadap Tingkat Kemiskinan Di Aceh.

Samuelson, Paul A dan William D.Nordhaus.1996. Makro Ekonomi (terjemahan). Edisi keempatbelas, Erlangga,Jakarta.

Santosa, Budi. 2013. Pengaruh Pendapatan Asli Daerah dan Dana Perimbangan daerah Terhadap Pertumbuhan, Pengangguran dan Kemiskinan 33 Provinsi di Indonesia. Jurnal Ekonomi dan Bisnis. Vol. 5, No. 2 Juli 2013.

Setiyawati, Anis dan Ardi Hamzah, 2007. "Analisis Pengaruh PAD, DAU, DAK dan Belanja Pembangunan Terhadap Pertumbuhan Ekonomi, Kemiskinan dan Pengangguran", Jurnal Akuntansi dan Keuangan Indonesia,

Shenggen, F. and P. Hazell. 2001. Returns to Public Investments in The Less-Favored Areas of India and China. American Journal of Agricultural Economics, 83 : 1217-1222.

Sepulveda, Cristian F., 2010, The Consequences of Fiscal Decentralization on Poverty and Inequality, George State University.

Sinegar, Hermanto dan Wahyuniarti, Dwi. 2006. Dampak Pertumbuhan Ekonomi Terhadap Penurunan Jumlah Penduduk Miskin.

Siregar, Hermanto. 2006. "Perbaikan Struktur dan Pertumbuhan Ekonomi: Mendorong Investasi dan Menciptakan Lapangan Kerja", Jurnal Ekonomi Politik dan Keuangan, INDEF, Jakarta.

Suliswanto, Muhammad Sri Wahyudi. 2010. Pengaruh Produk Domestik Bruto (PDB) dan Indeks Pembangunan Manusia (IPM) Terhadap Angka Kemiskinan di Indonesia. Jurnal Ekonomi Pembangunan, Vol 8 No. 2 Desember 2010.

Sukirno, Sadono. 2011. Makro Ekonomi Teori Pengantar. PT. Raja Grafindo Perkasa . Jakarta.

Suryadarma, D. dan A. Suryahadi. 2007. The Impact of Private Growth Sector on Poverty eduction: Evidence from Indonesia. SMERU Working Paper, April 2007.

Skira, Meghan, 2006, Fiscal Decentralization and Poverty, Andrew Young School of Policy Studies. 
Todaro, M. P. dan Stephen C. Smith. Pembangunan Ekonomi. 2008. Jakarta: Erlangga.

Uhise, Stepvani, 2013. "Dana Alokasi Umum pengaruhnya terhadap Pertumbuhan Ekonomi Sulawesi Utara dengan Belanja Modal sebagai Variabel Intervening", Jurnal EMBA, Volume 1 Nomor 4 hal 1677-1686.

Vera Wilhelm and Ignacio Fiestas, 2005, Exploring the Link Between Public Spending and Poverty Reduction: Lessons from the 90s, The International Bank for Reconstruction and Development/The World Bank, Washington DC.

Wong, John D. 2004. The Fiscal Impact of Economic Growth and Development on Local Government Revenue Capacity. J.Of Public Budgeting, Accounting \& Financial Management, 16(3), 413-423.

Widodo, Adi, Waridin Dan Maria K., Johanna. 2011. Analisis Pengaruh Pengeluaran Pemerintah Di Sektor Pendidikan Dan Kesehatan Terhadap Pengentasan Kemiskinan Melalui Peningkatan Pembangunan Manusia Di Provinsi Jawa Tengah. Jurnal Dinamika Ekonomi Pembangunan, Vol. 1.

Yao, Guevera Assamoi, 2007, Fiscal Decentralization and Poverty Reduction Outcomes: Theory and Evidence, George State University. 